\title{
Correlation between FOXP1 and ER/PR expression in endometrial carcinoma
}

\author{
Guannan $\mathbf{Y u}^{1,2,3}$, Huimin Wang ${ }^{4}$, Zhenhua $\mathrm{Hu}^{5}$, Song Zhang ${ }^{6}$, Yue $\mathbf{Q i}^{1,2,3}$, Juanjuan \\ Liu ${ }^{1}$, Liancheng Zhu ${ }^{1}$ and Bei Lin ${ }^{1,2,3}$ \\ ${ }^{1}$ Department of Obstetrics and Gynecology, Shengjing Hospital Affiliated to China Medical University, Shenyang, Liaoning \\ 110004, China \\ ${ }^{2}$ Key Laboratory of Maternal-Fetal Medicine of Liaoning Province, Benxi, Liaoning 117000, China \\ ${ }^{3}$ Key Laboratory of Obstetrics and Gynecology of Higher Education of Liaoning Province, Benxi, Liaoning 117000, China \\ ${ }^{4}$ Department of Obstetrics and Gynecology, Cancer Hospital of China Medical University, Shenyang, Liaoning 110042, China \\ ${ }^{5}$ Department of Obstetrics and Gynecology, The First Affiliated Hospital of Zhengzhou University, Zhengzhou, Henan 450052, \\ China \\ ${ }^{6}$ Department of Obstetrics and Gynecology, Dalian Maternity and Child Health Care Hospital, Dalian, Liaoning 116000, China \\ Correspondence to: Bei Lin, email: linbei88@hotmail.com \\ Keywords: endometrial carcinoma; FOXP1; ER; PR; estrogen treatment
}

Received: January 04, $2017 \quad$ Accepted: July 25, $2017 \quad$ Published: December 26, 2017

Copyright: $Y u$ et al. This is an open-access article distributed under the terms of the Creative Commons Attribution License 3.0 (CC BY 3.0), which permits unrestricted use, distribution, and reproduction in any medium, provided the original author and source are credited.

\section{ABSTRACT}

Objectives: To detect the expression of FOXP1 in endometrial carcinoma and analyze its correlation with estrogen receptor and progesterone receptor.

Methods: Expression of FOXP1, estrogen receptor and progesterone receptor was measured by immunohistochemistry in endometrial tissue acquired from patients. Interactions of FOXP1 with estrogen receptor and progesterone receptor were determined by confocal microscopy and co-immunoprecipitation. Expression change of FOXP1, estrogen receptor and progesterone receptor after estrogen or progesterone treatment was measured by western blotting and real-time PCR in Ishikawa cells. Transcriptional regulation was ascertained with chromatin immunoprecipitation.

Results: FOXP1 levels were lower in endometrial carcinoma than in atypical endometrial hyperplasia or normal endometrium. Estrogen receptor, progesterone receptor and the overall survival time were correlated with the expression of FOXP1. Colocalization were observed between FOXP1 and both estrogen receptor and progesterone receptor. Interactions were found between estrogen receptor $\beta$ with both FOXP1 and estrogen receptor $a$ in Ishikawa cells. Estrogen receptor and progesterone receptor increased after overexpression of FOXP1. FOXP1 and estrogen receptor exhibited similar changes in both concentration-dependent and timedependent manner following estradiol or progesterone treatment. Estrogen receptor bound to the transcriptional regulatory regions of FOXP1.

Conclusions: FOXP1 is poorly expressed in endometrial carcinoma and associated with the low expression of estrogen receptor and progesterone receptor, as well as the shorter survival time. Estrogen receptor $\beta$ interacts with both FOXP1 and estrogen receptor $a$ in Ishikawa cells; FOXP1 is influenced by estradiol and progesterone. Its transcription can be regulated by estrogen receptor. 


\section{INTRODUCTION}

Endometrial carcinoma is one of three most common malignancies of the female reproductive system; its morbidity trend has increased in recent years, and its mortality is the second highest, after ovarian cancer, in several developed countries [1]. The majority of endometrial carcinoma cases occur in postmenopausal women, but endometrial carcinoma has tended to affect younger women in recent years. For patients with advanced metastasis or recurrent endometrial carcinoma, only limited therapies are available, and combined chemoradiotherapy and new molecular-targeted chemotherapeutics both have no obvious efficacy [2]. At present, the pathogenesis of endometrial carcinoma has not been clearly clarified, but it is recognized that the estrogen-estrogen receptor (ER) theory plays a role in the occurrence and development of endometrial carcinoma [3].

Forkhead box protein 1 (FOXP1), a member of the forkhead transcriptional factor family, also known as MFH, QRF1 or hFKH1B, is widely present in several types of normal organ cells and has many physiological functions. It plays an important role in the regulation of $\mathrm{B}$ cell development and monocyte differentiation, and participates in cardiac valve morphodifferentiation and lung development [4]. Numerous studies have shown that the expression level of FOXP1 shows a marked change in tumor tissues, being lower in renal, breast, ovarian, lung and prostate cancers than in normal tissues [5-10], but is increased in malignant tumors such as lymphoma, which indicates that FOXP1 may have other roles except as an anti-oncogene [11-13].

Current studies have suggested that FOXP1 is highly expressed in endometriosis, but its nucleus expression is absent in Stage I endometrial carcinoma; the absence of FOXP1 nucleus expression is the most significant manifestation of endometrial adenocarcinoma. According to available reports, however, the positive expression rate of FOXP1 in the cytoplasm varies greatly, from negative to $90 \%$ (median: $30 \%$ ) $[14,15]$. Our preliminary study demonstrated that the mRNA expression level of FOXP1 was decreased in highly metastatic and drug-resistant ovarian cancer cell lines associated with ovarian cancer metastasis [10]. With increasing malignancy of ovarian tumors, the nucleus expression of FOXP1 became reduced, and FOXP1 and the ER co-localized in the cytoplasm; coimmunoprecipitation experiments showed that FOXP1 bound both ER $\alpha$ and ER $\beta$ [5]. Currently, only studies concerning FOXP1 expression in Stage I endometrial carcinoma exist, but there is an absence of completed studies that focus on the roles of FOXP1, together with the ER, in endometrial carcinoma.

In the present study, we detected the expression of FOXP1, ER and progesterone receptor(PR) in endometrial tissues at different stages and of different pathological types, then analyzed the relationship between FOXP1 expression and clinical pathological parameters and the prognosis of endometrial carcinoma. We also demonstrated the interactions of FOXP1 with ER and PR in endometrial carcinoma tissues.

\section{RESULTS}

\section{FOXP1 expression in endometrial tissues of various groups}

FOXP1 was stained in both the nucleus and cytoplasm, and expression intensities showed a significantly positive correlation $(\mathrm{r}=0.324, P=0.002)$. In the study of FOXP1 expression, all cases were divided into either a weakly positive FOXP1 expression group $(-/+)$ or a strongly positive FOXP1 expression group $(++/+++)$. nucleus staining for FOXP1 was strongly positive in $7.80 \%$ of cells in the endometrial carcinoma group, significantly lower than that for endometrial atypical hyperplasia $(25 \%, P=0.033)$ and normal endometrium groups $(58.33 \%, P=2.190 \mathrm{E}-04)$. Strongly positive expression of FOXP1 was noted in the cytoplasm of $10 \%$ of cells in the endometrial carcinoma group, which was also markedly lower than that for endometrial atypical hyperplasia $(53.57 \%, P=5.664 \mathrm{E}-07)$ and normal endometrium groups $(41.67 \%, P=0.011)$. For mild, moderate and severe endometrial atypical hyperplasia groups, the nucleus expression of FOXP1 was strongly positive in $50 \%, 25 \%$ and $0 \%$ of cells, respectively, showing an evidently decreasing trend with increased severity of disease; however, significant differences were not found $(P>0.05)$. For the expression of FOXP1 in the cytoplasm, $50 \%, 75 \%$ and $40 \%$ of cells were strongly stained respectively, the differences were not significant $(P>0.05)$. The nucleus strongly positive expression of FOXP1 was $50 \%$ and $33.3 \%$ in the secretory and proliferative normal endometrium groups, respectively, but differences were not statistically significant $(P>0.05)$. The cytoplasm strongly positive expression of FOXP1 was $33.3 \%$ and $50 \%$ in the secretory and proliferative normal endometrium groups, respectively, differences were not statistically significant either $(P>0.05)$ (Table 1, Figure 1).

\section{Relationship between FOXP1 expression and clinical pathological parameters of endometrial carcinoma}

90 cases of endometrial carcinoma in total were included in this study. The strongly positive nucleus expression rate $(23.3 \%)$ and strongly positive cytoplasmic expression rate(30.0\%) for FOXP1 in ER positive group were both significantly higher than those in ER negative group ( $0 \%, P=0.002 ; 0 \%, P=2.422 \mathrm{E}-04$, respectively). The strongly expression of FOXP1 in the nucleus (20.6\%) and cytoplasm (23.5\%) in cells of PR positive group was also 
Table 1: Expression of FOXP1 in different kind of endometrial tissue

\begin{tabular}{|c|c|c|c|c|c|c|c|c|c|c|c|}
\hline \multirow{2}{*}{ Characteristics } & \multirow{2}{*}{ Cases } & \multicolumn{5}{|r|}{ Nucleus } & \multicolumn{5}{|c|}{ Cytoplasm } \\
\hline & & - & + & ++ & +++ & Strongly positive rate $(\%)$ & - & + & ++ & +++ & Strongly positive rate(\%) \\
\hline Malignant & 90 & 60 & 23 & 6 & 1 & $7.80 \%{ }^{\mathrm{a}}$ & 60 & 21 & 7 & 2 & $10.00 \%{ }^{\mathrm{b}}$ \\
\hline Atypical & 28 & 6 & 15 & 4 & 3 & $25.00 \%$ & 0 & 13 & 15 & 0 & $53.57 \%$ \\
\hline Severe & 10 & 3 & 7 & 0 & 0 & $0.00 \%$ & 0 & 6 & 4 & 0 & $40.00 \%$ \\
\hline Moderate & 8 & 2 & 4 & 1 & 1 & $25.00 \%$ & 0 & 2 & 6 & 0 & $75.00 \%$ \\
\hline Mild & 10 & 1 & 4 & 3 & 2 & $50.00 \%$ & 0 & 5 & 5 & 0 & $50.00 \%$ \\
\hline Normal & 12 & 2 & 3 & 5 & 2 & $58.33 \%$ & 0 & 7 & 4 & 1 & $41.67 \%$ \\
\hline Proliferative & 6 & 1 & 3 & 1 & 1 & $33.30 \%$ & 0 & 3 & 3 & 0 & $50.00 \%$ \\
\hline Secretory & 6 & 1 & 2 & 2 & 1 & $50.00 \%$ & 0 & 4 & 1 & 1 & $33.33 \%$ \\
\hline
\end{tabular}

Note: Comparison of the strongly expression rate of FOXP1 in endometrial carcinoma and endometrial atypical hyperplasia groups $\left(P<0.05\left[P^{\mathrm{a}}=0.033, P^{\mathrm{b}}=5.664 \mathrm{E}-07\right]\right)$. Comparison of the strongly expression rate of FOXP1 in endometrial carcinoma and normal endometrium groups $\left(P<0.05\left[P^{\mathrm{a}}=2.190 \mathrm{E}-04, P^{\mathrm{b}}=0.011\right]\right)$.

markedly higher than that in the PR negative group $(0 \%$, $P=0.006 ; 2.3 \%, P=0.011$, respectively). The strongly expression of FOXP1 in nucleus in both well-differentiated $(5.9 \%)$ and moderately differentiated (18.5\%) endometrial carcinoma was higher than that in poorly differentiated endometrial carcinoma ( $0 \%$ ); however, differences were not statistically significant $(P>0.05)$. While the strongly expression of FOXP1 in cytoplasm decreased when the degree of differentiation became low $(P=0.002)$. Among groups of different diagnostic age, FIGO(International Federation of Gynecology and Obstetrics) stage, pathological type, myometrial invasion, lymph nodes metastasis and distant metastasis, significant differences in the expression of FOXP1 were not found (Table 2).

\section{Low FOXP1 nucleus expression in endometrial carcinoma significantly correlated with shortened overall survival time}

By March 2016, follow-up over 30-140 months was complete. In 90 cases of endometrial carcinoma, 22 cases died of recurrence, 3 cases survived with recurrence, 49 cases survived without tumors and 16 cases were lost to follow-up. Kaplan-Meier analysis showed that the FIGO stage and the weakly expression rate of FOXP1 were both markedly related to shortened overall survival time $(P<0.001, P<0.01$, respectively) (Figure 2). A correlation was not found between diagnostic age, differentiation degree, myometrial invasion degree, ER or PR and survival time $(P=0.060, P=0.234, P=0.062, P=0.145$, $P=0.220$, respectively).
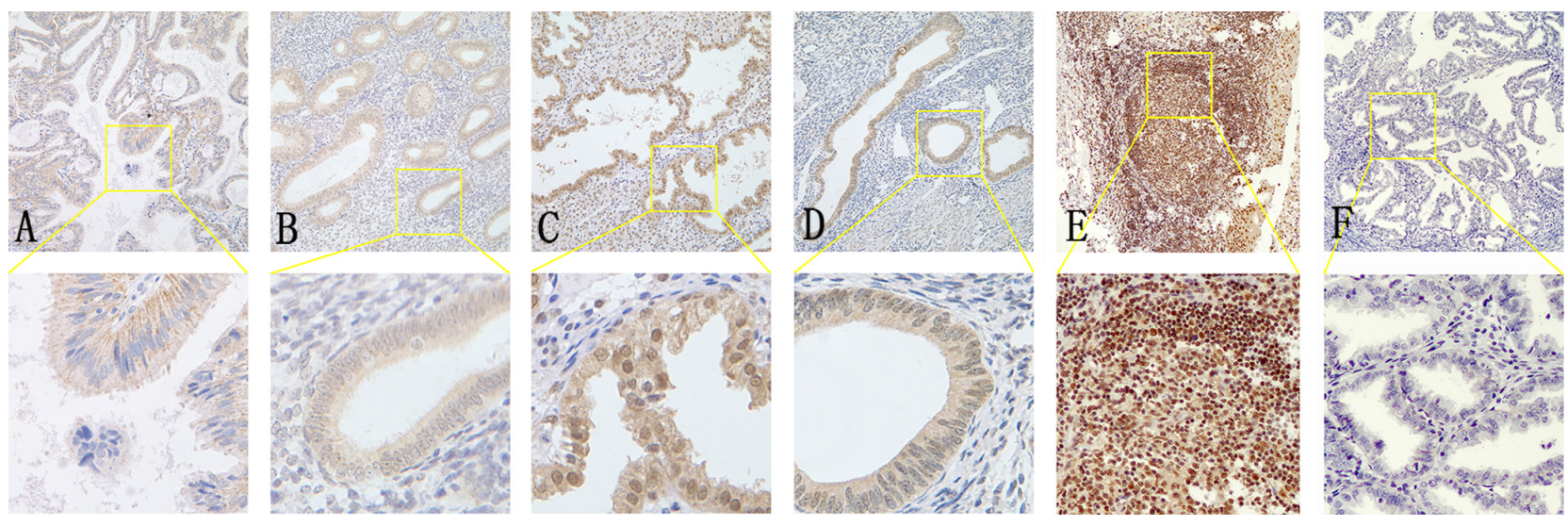

Figure 1: Expression of FOXP1 in various endometrium (400×). 
Table 2: The relationship between FOXP1 expression and clinical pathological factors in 90 cases of endometrial ade nocarcinoma

\begin{tabular}{|c|c|c|c|c|c|c|c|c|}
\hline \multirow[b]{2}{*}{ Parameters } & & \multirow[b]{2}{*}{ Cases } & \multicolumn{3}{|c|}{ Nucleus } & \multicolumn{3}{|c|}{ Cytoplasm } \\
\hline & & & $\begin{array}{l}\text { Weakly } \\
\text { positive }\end{array}$ & $\begin{array}{c}\text { Strongly } \\
\text { positive }\end{array}$ & Pvalue & $\begin{array}{l}\text { Weakly } \\
\text { positive }\end{array}$ & $\begin{array}{c}\text { Strongly } \\
\text { positive }\end{array}$ & Pvalue \\
\hline \multirow{2}{*}{ Age(years) } & $<59$ & 48 & $43(89.6 \%)$ & $5(10.4 \%)$ & \multirow{2}{*}{0.545} & $42(87.5 \%)$ & $6(12.5 \%)$ & \multirow{2}{*}{0.622} \\
\hline & $\geq 59$ & 42 & $40(95.2 \%)$ & $2(4.8 \%)$ & & $39(92.9 \%)$ & $3(7.1 \%)$ & \\
\hline \multirow{2}{*}{ FIGO stage } & $\mathrm{I}+\mathrm{II}$ & 63 & $56(88.9 \%)$ & $7(11.1 \%)$ & \multirow{2}{*}{0.169} & $56(88.9 \%)$ & $7(11.1 \%)$ & \multirow{2}{*}{0.088} \\
\hline & III+IV & 27 & $27(100.0 \%)$ & $0(0.0 \%)$ & & $25(92.6 \%)$ & $2(7.4 \%)$ & \\
\hline \multirow{4}{*}{ Histology } & Endometrioid & 42 & $37(88.1 \%)$ & $5(11.9 \%)$ & \multirow{4}{*}{0.091} & $35(83.3 \%)$ & $7(16.7 \%)$ & \multirow{4}{*}{0.225} \\
\hline & Serous & 20 & $20(100.0 \%)$ & $0(0.0 \%)$ & & $19(95.0 \%)$ & $1(5.0 \%)$ & \\
\hline & Clear cell & 17 & $17(100.0 \%)$ & $0(0.0 \%)$ & & $17(100.0 \%)$ & $0(0.0 \%)$ & \\
\hline & Others $^{\text {a }}$ & 11 & $9(81.8 \%)$ & $2(18.2 \%)$ & & $11(90.9 \%)$ & $1(9.1 \%)$ & \\
\hline \multirow{3}{*}{ Differentiation $^{b}$} & Well & 17 & $16(94.1 \%)$ & $1(5.9 \%)$ & \multirow{3}{*}{0.099} & $13(76.5 \%)$ & $4(23.5 \%)$ & \multirow{3}{*}{0.002} \\
\hline & Moderate & 26 & $21(81.5 \%)$ & $5(18.5 \%)$ & & $23(88.5 \%)$ & $3(11.5 \%)$ & \\
\hline & Poor & 21 & $21(100.0 \%)$ & $0(0.0 \%)$ & & $21(100.0 \%)$ & $0(0.0 \%)$ & \\
\hline \multirow{2}{*}{$\mathrm{ER}^{\mathrm{c}}$} & - & 48 & $48(100.0 \%)$ & $0(0.0 \%)$ & \multirow{2}{*}{0.002} & $48(100.0 \%)$ & $0(0.0 \%)$ & \multirow{2}{*}{$2.422 \mathrm{E}-04$} \\
\hline & + & 30 & $23(76.7 \%)$ & $7(23.3 \%)$ & & $21(70.0 \%)$ & $9(30.0 \%)$ & \\
\hline \multirow{2}{*}{$\mathrm{PR}^{\mathrm{d}}$} & - & 44 & $44(100.0 \%)$ & $0(0.0 \%)$ & \multirow{2}{*}{0.006} & $43(97.7 \%)$ & $1(2.3 \%)$ & \multirow{2}{*}{0.011} \\
\hline & + & 34 & $27(79.4 \%)$ & $7(20.6 \%)$ & & $26(76.5 \%)$ & $8(23.5 \%)$ & \\
\hline \multirow{2}{*}{ Muscular invasion } & $<1 / 2$ & 52 & $46(88.5 \%)$ & $6(11.5 \%)$ & \multirow{2}{*}{0.246} & $45(86.5 \%)$ & $7(13.5 \%)$ & \multirow{2}{*}{0.355} \\
\hline & $\geq 1 / 2$ & 38 & $37(97.4 \%)$ & $1(2.6 \%)$ & & $36(94.7 \%)$ & $2(5.3 \%)$ & \\
\hline \multirow{2}{*}{$\begin{array}{l}\text { Lymph nodes } \\
\text { metastasis }\end{array}$} & - & 53 & $49(92.5 \%)$ & $4(7.5 \%)$ & \multirow{2}{*}{0.447} & $49(92.5 \%)$ & $4(7.5 \%)$ & \multirow{2}{*}{0.147} \\
\hline & + & 22 & $22(100.0 \%)$ & $0(0.0 \%)$ & & $17(77.3 \%)$ & $5(22.7 \%)$ & \\
\hline
\end{tabular}

Note: a. "Others" include 2 cases of mucinous adenocarcinoma, 2 cases of squamous cell carcinoma, 2 cases of undifferentiated carcinoma, 1 case of small cell carcinoma and 1 case of mixed carcinoma; b. Represented 26 patients without detail information of differentiation; c. Represented 12 patients without ER detection; d. Represented 12 patients without PR detection; e. Represented 15 patients without lymphadenectomy.

\section{Interactions of FOXP1 with ER $\alpha$, ER $\beta$ and PR detected in the ishikawa cells and endometrial carcinoma tissues}

The results of immunofluorescence confocal microscopy revealed that FOXP1 and ER or PR colocalized in the nucleus, cytoplasm especially around the nucleus in cells of the Ishikawa cells and endometrial carcinoma tissues (Figure 3). The most obvious colocalization was FOXP1 and ER $\beta$ (Figure 3B). Coimmunoprecipitation results suggested that FOXP1 and $\mathrm{ER} \beta, \mathrm{ER} \alpha$ and ER $\beta$ interacted in the Ishikawa cells, indicating a possible interaction of FOXP1 with ER (Figure 4). Lane 1 represented a positive control (total protein lysate), lane 2 represented a negative control(rabbit $\mathrm{LgG}$ ), and lane 3 was where the target bands located.

\section{Changes in ER $\alpha, E R \beta$ and PR expression after up-regulation of FOXP1 expression}

After FOXP1 up-regulation, the relative mRNA expression of FOXP1 increased by $1.5 \mathrm{E}+07$ times compared with the empty control, the relative protein expression of FOXP1 increased by 12 times compared with the empty control. The relative mRNA expression of $E R \alpha, E R \beta$ and $P R$ all significantly increased after FOXP1 overexpression (3.5 times, 6.0 times and $8.3 \mathrm{E}+05$ times, respectively. $P<0.05$ ). The relative protein expression of $\mathrm{ER} \alpha, \mathrm{ER} \beta$ and $\mathrm{PR}$ all significantly increased after FOXP1 

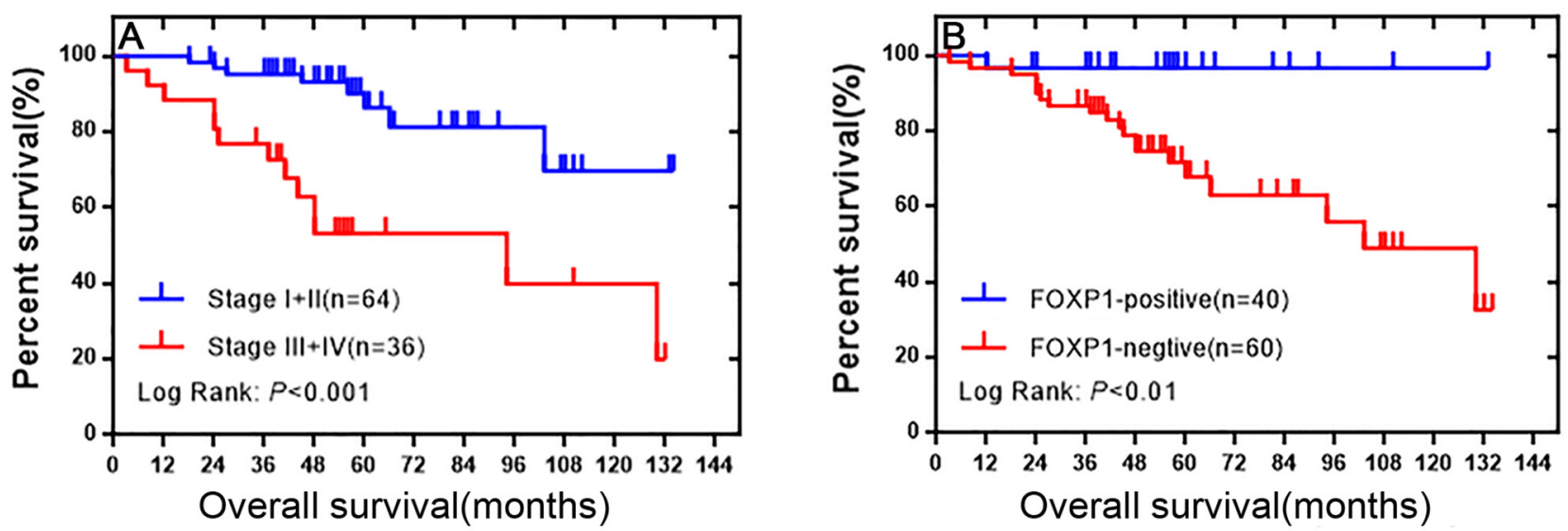

Figure 2: Kaplan-Meier survival curves according to FOXP1 expression and FIGO stage.

A
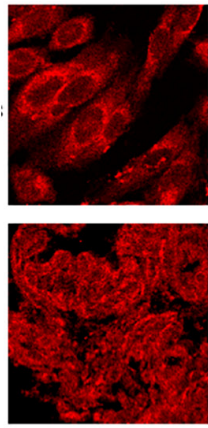

FOXP1

B
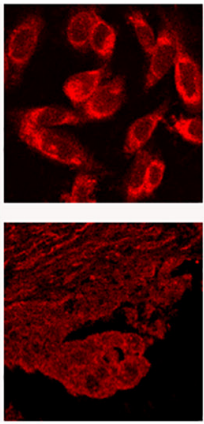

FOXP1

C
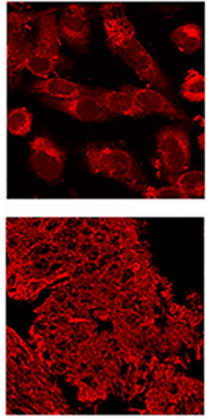

FOXP1
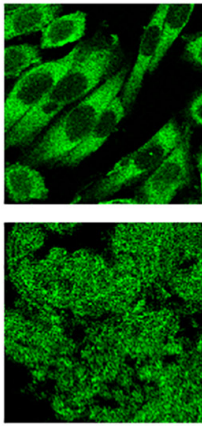

ERa
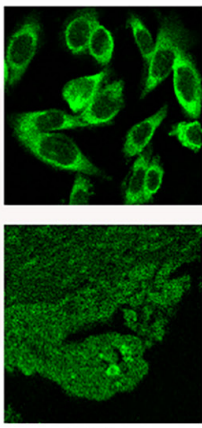

$\mathrm{ER} \beta$
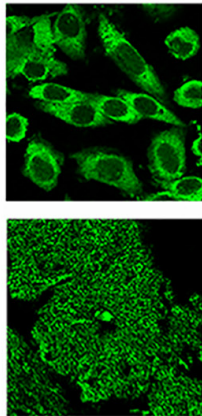

PR
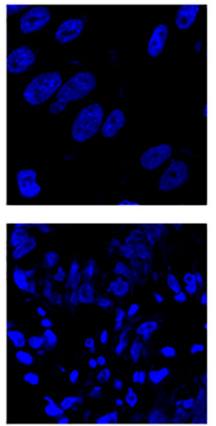

nucleus
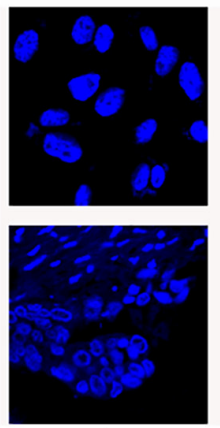

nucleus
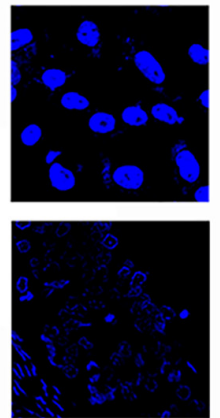

nucleus
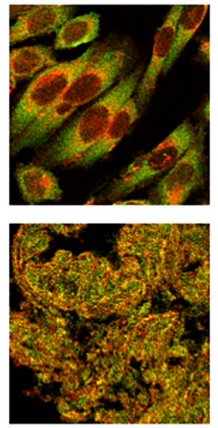

merge
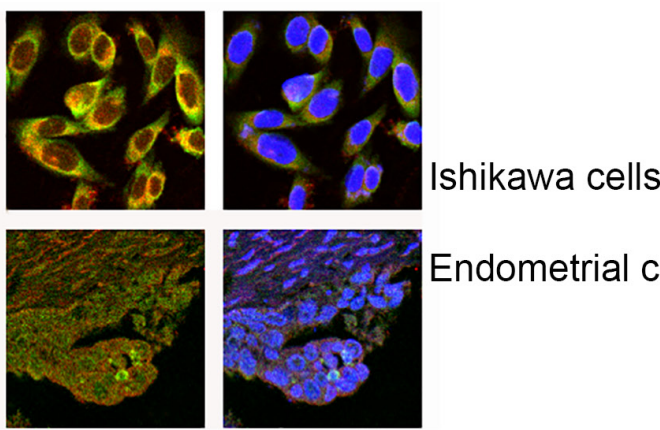

merge

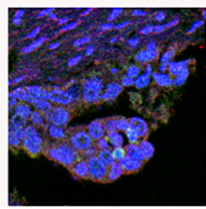

Endometrial carcinoma tissue

merge+nucleus
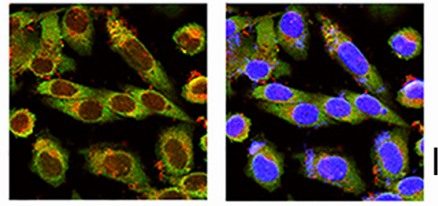

Ishikawa cells

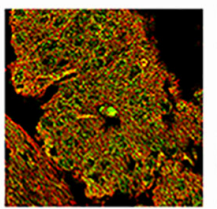

merge

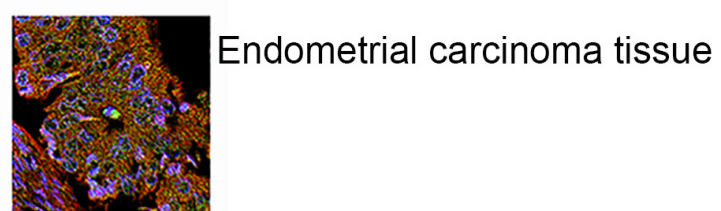

merge+nucleus

Figure 3: Immunofluorescent double staining was performed to by confocal microscopy assess. 
overexpression (2.2 times, 6.6 times and 2.2 times, respectively. $P<0.01$ ) (Figure 5). In short, the expression of ER and PR all significantly increased after FOXP1 overexpression.

\section{Changes in FOXP1 expression in ishikawa cells exposed to estrogen or progesterone}

After adding $1 \times 10^{-8}, 1 \times 10^{-7}, 1 \times 10^{-6}$ and $1 \times 10^{-5}$ $\mathrm{mol} / \mathrm{L}$ (final concentration) estradiol or progesterone to the medium of Ishikawa cells, the expression of FOXP1, ER and PR was measured. Real-time PCR results indicated that expression changes of ER $\alpha, E R \beta, F O X P 1$ and $P R$ were similar, and both trended to decrease. $P R$ increased finally as the concentration of estradiol reached $1 \times 10^{-5}$ mol/L (Figure 6A). Protein expression was not exactly the same as mRNA expression, but FOXP1, ER $\alpha$ and ER $\beta$ were found to show a similarly decreasing trend with an increase in estradiol concentrations. PR tended to increase slightly (Figure 6D). During the first 5 hours after the treatment of estradiol, FOXP1,ER $\alpha, E R \beta$ and $P R$ decreased slowly. After that, they began to increase quickly (Figure 6B). When treated with estradiol, FOXP1, $\mathrm{ER} \alpha$ and ER $\beta$ usually changed in a same way, while PR changed in a opposite way sometimes.

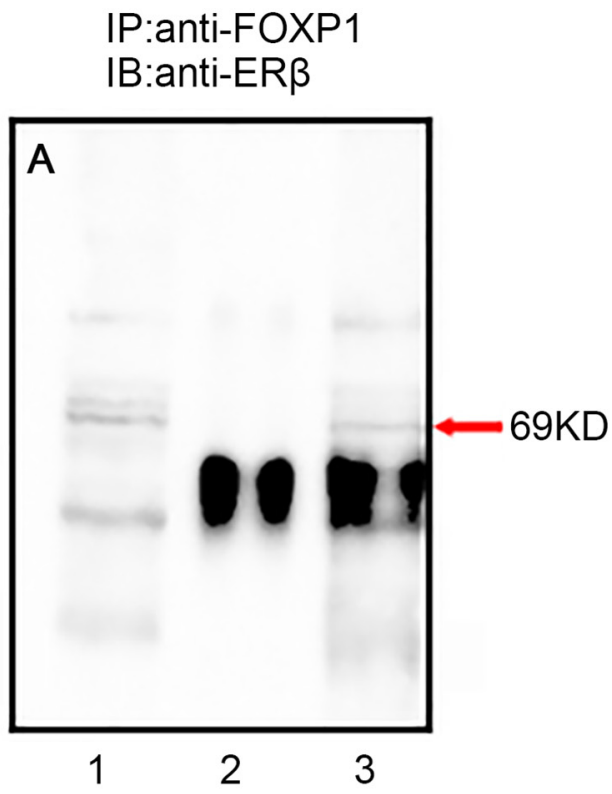

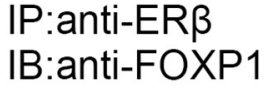
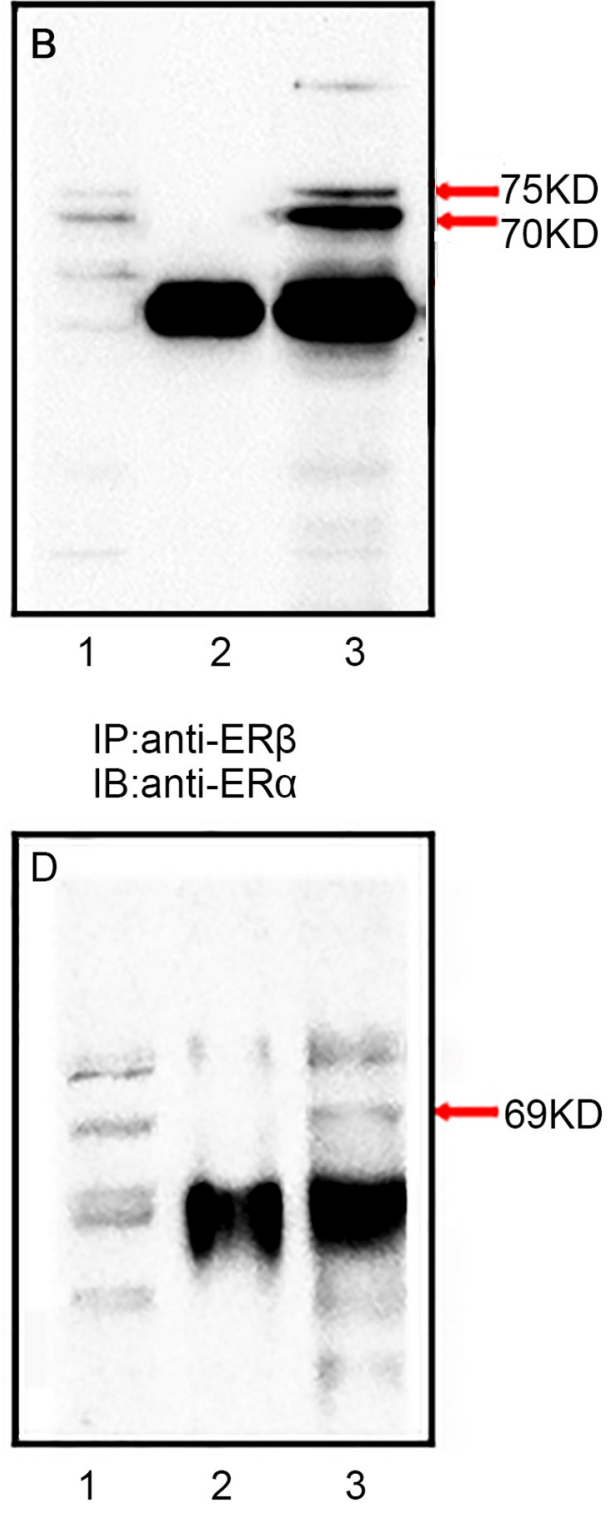

Figure 4: Co-immunoprecipitation performed to detect the interaction of FOXP1 and ER $\beta, E R \alpha$ and ER 
After adding progesterone at the same concentrations as estradiol to the medium of Ishikawa cells, the expression of ER $\alpha, \mathrm{ER} \beta$, FOXP1 and PR firstly decreased and then increased (Figure 7A, 7D). During the first 7 hours after the treatment of progesterone, FOXP1, $E R \alpha, E R \beta$ and $P R$ increased gradually. After that, FOXP1, $E R \alpha$ and $P R$ began to decrease. $E R \beta$ continued to increase but in a slower speed (Figure 6B). A synchronous trend in protein and mRNA expression for FOXP1, ER $\alpha, E R \beta$ and PR was noted (Figure 7).

\section{Binding of ER to the transcriptional regulatory region of $\mathrm{FOXP1}$ by chromatin immunoprecipitation (ChIP) assay in the ishikawa cells}

The Ishikawa cells was routinely cultured for ChIP analysis with $\mathrm{ER} \alpha$ or $\mathrm{ER} \beta$ specific antibodies.
Immunoprecipitated DNA fragments were detected by real-time PCR and the relative expression to $\beta$-actin control was calculated. The estrogen response element (TFF1 ERE) of the TFF1 gene was used as a positive control. The results showed that both $\mathrm{ER} \alpha$ and $\mathrm{ER} \beta$ could bind to the transcriptional regulatory region of FOXP1. Since the expression of ER $\beta$ mRNA and protein in Ishikawa cells was significantly higher than that of ER $\alpha$, the ChIP results showed that the fragments of FOXP1 that bind to ER $\alpha$ were more than that could bind to ER $\beta$. It suggested that ER $\alpha$ played a more important role in regulation of FOXP1 compared with ER $\beta$ (Figure 8).

\section{DISCUSSION}

FOXP1, a member of the forkhead transcriptional factor family, is known to exist widely in tumor cells, B cells and monocytes. FOXP1 plays an important role in

A

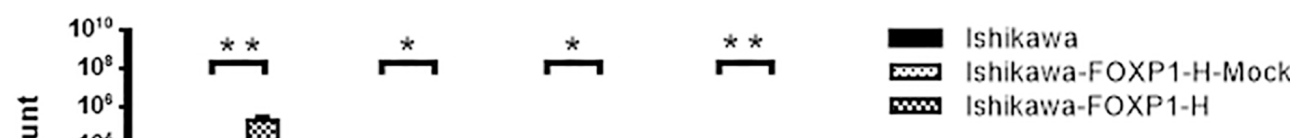

B

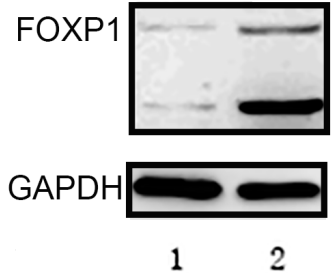

ERa<smiles>C#CCC#C</smiles>

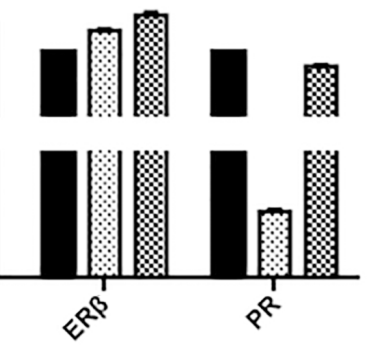

m Ishikava-FOXP1-H

C

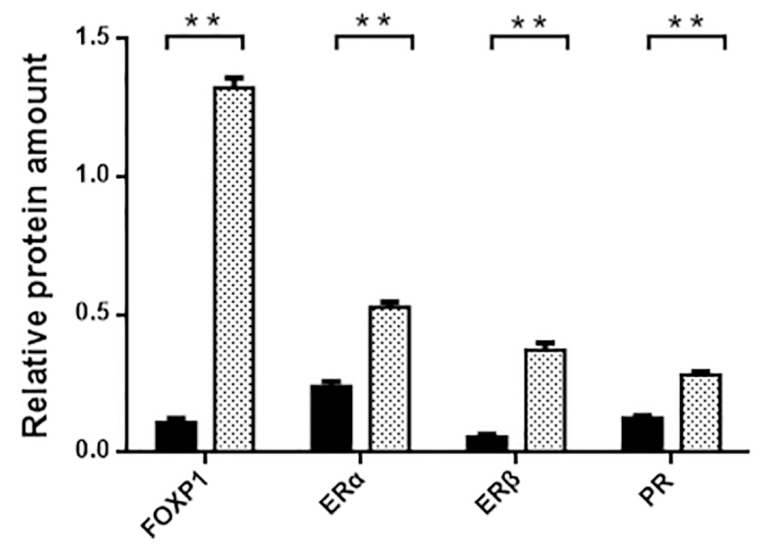

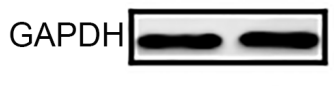

12

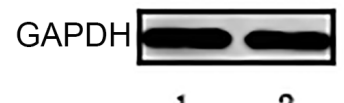

12

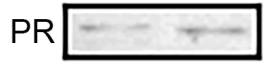

GAPDH

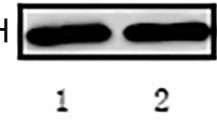

Ishikawa-FOXP1-H-Mock

Ishikawa-FOXP1-H

Figure 5: Expression of ER and PR after overexpression of FOXP1 in Ishikawa cells. 


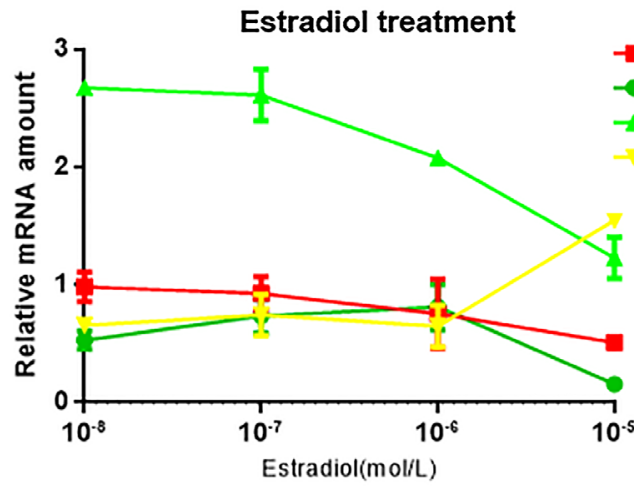

C

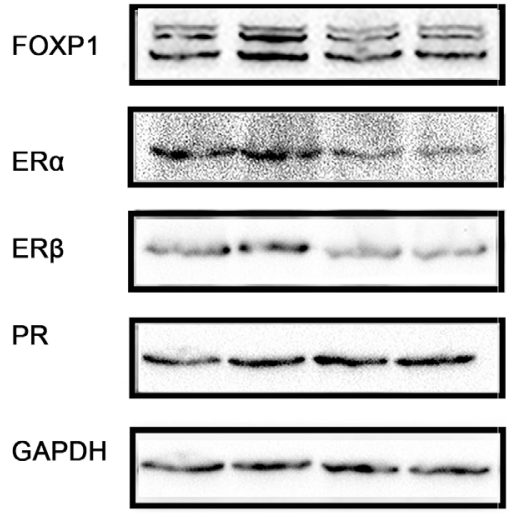

$B$

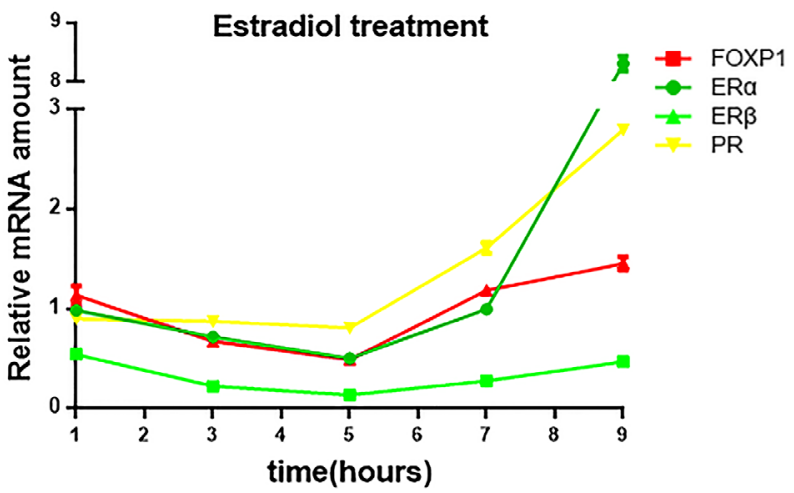

D

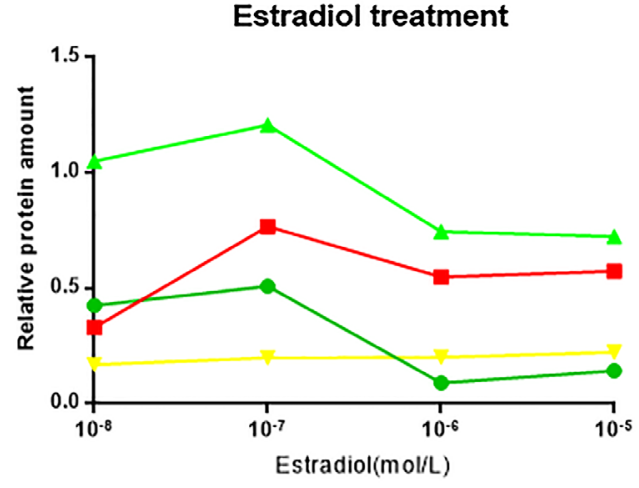

Figure 6: Expression change of FOXP1, ER and PR after estradiol treatment.

A

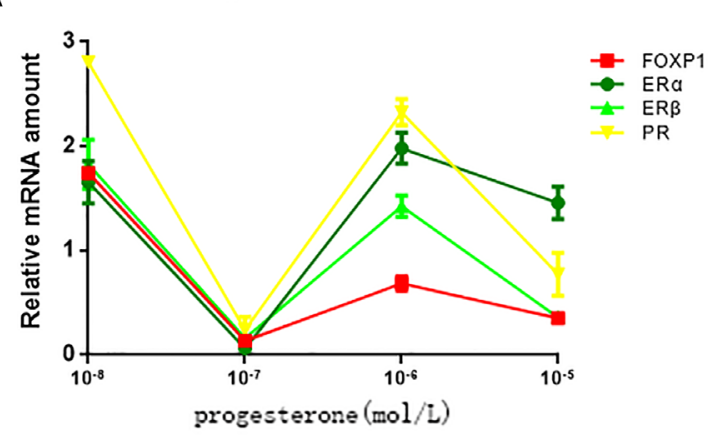

C

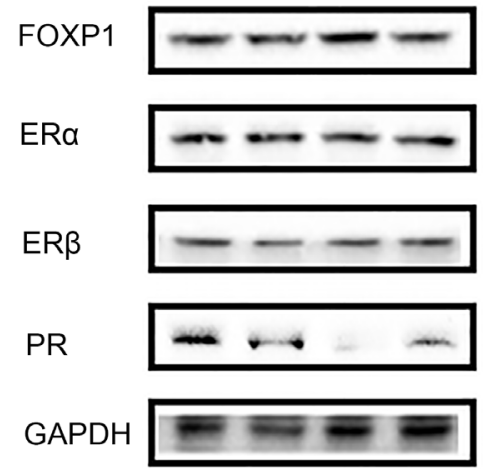

$\mathrm{B}$

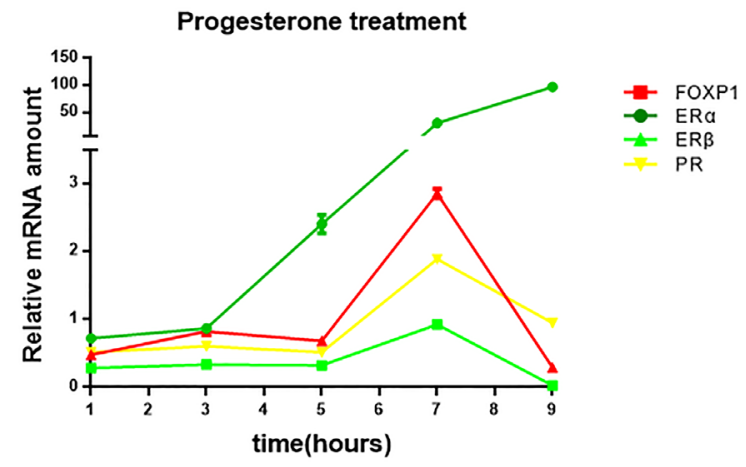

D

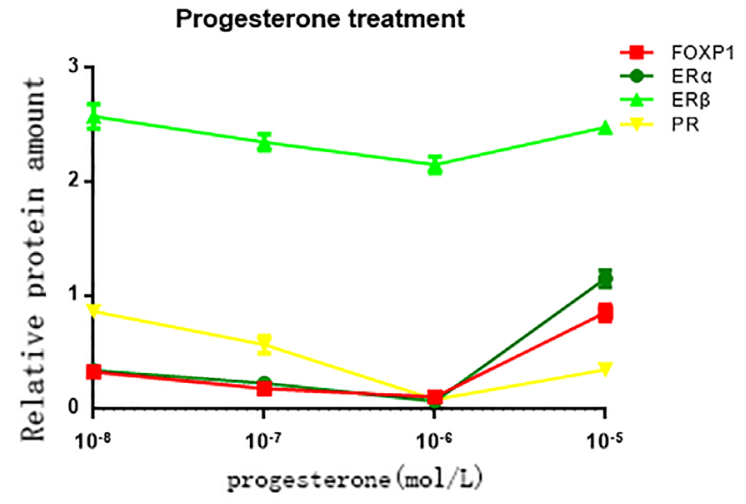

Figure 7: Expression change of FOXP1, ER and PR after progesterone treatment. 
the regulation of embryo development, B cell development and monocyte differentiation, and participates in cardiac valve morphodifferentiation and lung development [4, 11]. FOXP1 can bind to specific DNA-binding regions and thus regulate gene transcription; in most tumors, it functions as an anti-oncogene.

Our research group found that FOXP1 and ER interacted, as determined by co-immunoprecipitation, in ovarian cancer. We also found that FOXP1 displayed intracellular expression locations and trends that were similar to those of ER $\beta$. FOXP1 participates in the malignant progression of ovarian cancer as a tumorinhibiting factor [5]. In breast cancer, it has been shown that FOXP1 and ER can bind with each other in their transcriptional regulation regions to influence their transcription. Which leads onto questions on the expression and role of FOXP1 in endometrial carcinoma, and whether FOXP1 can also interact with ER to participate in the occurrence and development of endometrial carcinoma.

Loss of expression of FOXP1 in endometrial carcinoma has already been observed by some scholars
[5]. Mizunuma also found FOXP1 down-regulated in grade 3 endometrial carcinoma comparing with grade 1 or 2 [16]. We detected FOXP1 expression in endometrial carcinoma, endometrial atypical hyperplasia and normal endometrium by immunohistochemistry. We found that FOXP1 was simultaneously located in the nucleus and cytoplasm; its expression level in nucleus and cytoplasmic showed a significant positive correlation. The strongly positive rate of FOXP1 in nucleus and cytoplasm was significantly lower in endometrial carcinoma than in endometrial atypical hyperplasia and normal endometrium. The nucleus expression of FOXP1 in the endometrial atypical hyperplasia group markedly decreased in line with severity of disease. Survival analysis showed that the low expression of FOXP1 was related to a shortened survival time. Expression of FOXP1 correlated positively with the expression of ER and PR.

Studies have suggested that FOXP1 participates in the regulation of immune function, and its absence of expression may result in a serious defect in the early development of B cells and thus inhibit the immune function of the body [17], which is a possibly important

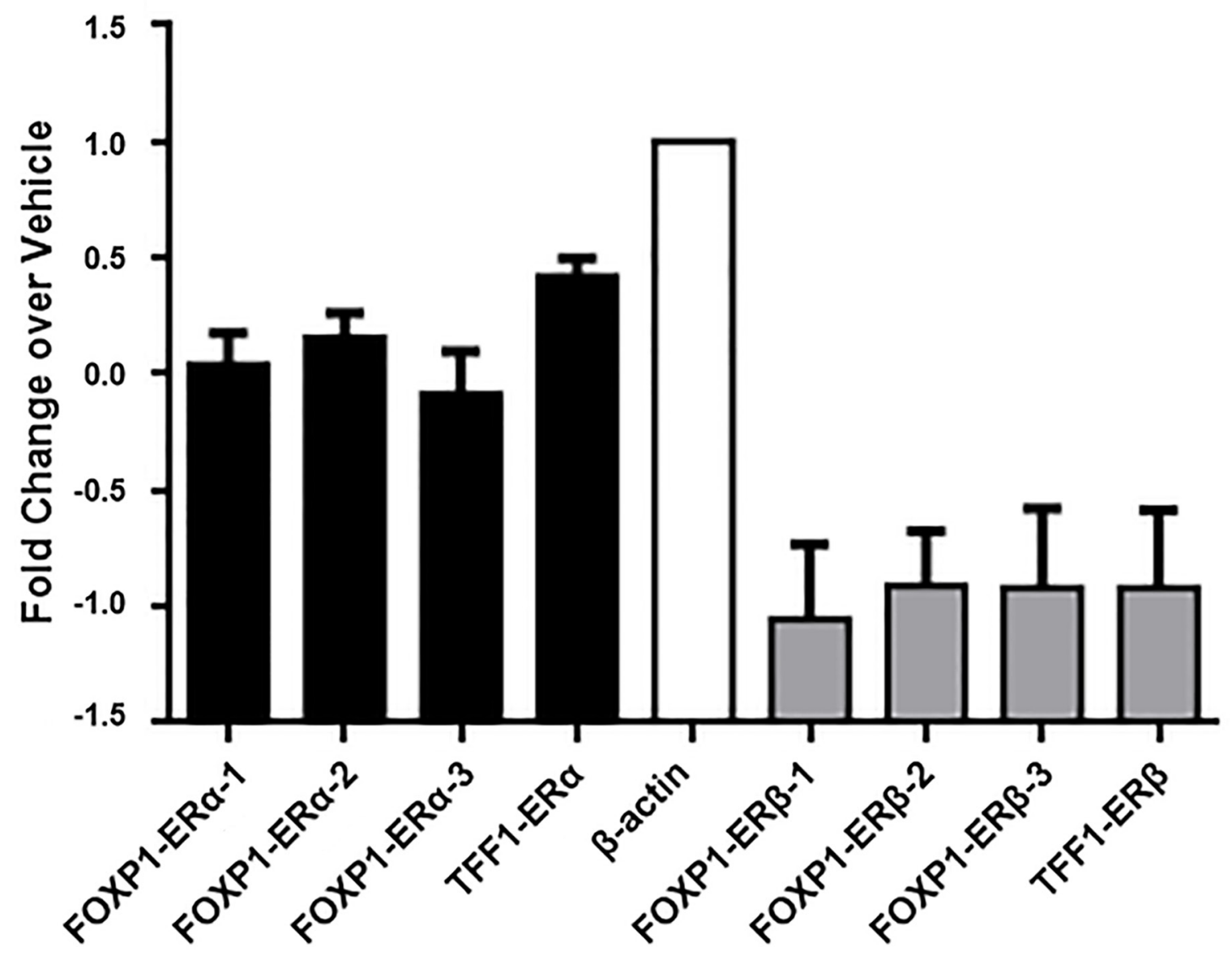

Figure 8: Identification of ER binding sites in transcriptional regulatory region of FOXP1 by ChIP strategy. 
cause for the poor prognosis of patients with low FOXP1 expression. On the other hand, it has been found in breast cancer studies that FOXP1 and FOXA1 double positive patients are sensitive to tamoxifen and have a better outcome. One important explanation for this discrepancy is that patients with low FOXP1 expression show decreased ER expression and are therefore insensitive to ER blockers, leading to shortened survival time [18]. Large-size survival analysis studies of endometrial carcinoma have revealed that the expression of the ER and PR are closely associated with patients' survival; patients showing high expression of ER and PR show a long survival time, a low death rate and have a good outcome. The efficacy of hormonal therapy is also related to the expression of ER and PR in endometrial carcinoma patients; the response rate of ER and PR double positive patients is $80 \%$ which is higher than that of ER-positive only, PR-positive only, or ER and PR double negative patients, so that patients with low FOXP1 expression are more likely to be less sensitive to hormone therapy and thus have a poor prognosis. In summary, we found that FOXP1 expression was decreased in endometrial carcinoma and showed a decreasing trend with severity of disease in endometrial atypical hyperplasia. FOXP1 expression positively correlated with the expression of ER and PR, and the low expression of FOXP1 was associated with a poor prognosis in endometrial carcinoma patients. This suggests that FOXP1 has a tumor-inhibiting effect in the occurrence and development of endometrial carcinoma, and its expression may be related to the expression of ER and PR.

In breast cancer, FOXP1 is an estrogen-induced transcriptional factor and its expression is associated with $\mathrm{ER} \alpha, \mathrm{ER} \beta$ and the PR $[7,19]$. In order to confirm a similar role for FOXP1 in endometrial carcinoma, we exposed Ishikawa cells to increasing concentrations of estradiol and then measured the expression of FOXP1, ER $\alpha, E R \beta$ and PR. FOXP1, ER $\alpha$ and ER $\beta$ decreased with estradiol concentration increasing, except PR. An explanation for this result may be that estradiol shows a negative feedback mechanism against ER and FOXP1 expression, while estradiol can regulate the expression of $\mathrm{PR}$ in a positive feedback manner. The protein expression of FOXP1, ER $\alpha$ and ER $\beta$ gradually decreased with increasing estradiol concentration and demonstrated the same trend. PR increased gradually to antagonize its effect. This can explain why patients with endometrial carcinoma often have high estrogen levels and low FOXP1. In progesterone treatment experiments, expression of FOXP1, ER and PR are all affected by progesterone in quit a similar way. The mechanism is not clear and worth to be studied in the future.

Some studies have shown that FOXP1 and FOXA1, members of the forkhead transcriptional factor family, can both bind to the transcriptional regulation region of ER. FOXP1 and ER can thus mutually regulate their transcription $[7,18]$. In previous studies of breast cancer, it was found that estradiol formed a complex with ER, CoR(nucleus receptor coactivator 1) and AP1(AP-1 transcription factor subunit)/SP1(Transcription factor Sp1). The complex then bound to DNA in a transcriptionregulating role to thus impact cell proliferation and the cell cycle. ER and SP1 in this complex bound the transcriptional regulation region of FOXP1 to influence FOXP1 expression, which may be the mechanism by which estradiol affects FOXP1 expression. On the other hand, progesterone also formed a complex with PR and $\mathrm{CoP}$, and the complex subsequently bound DNA to impact cell proliferation by regulating the expression of Wnts and RANKL. We made a FOXP1-overexpressing IshikawaFOXP1-H cell line by transfecting with lentivirus and then comparatively analyzed the expression levels of the ER and PR after transfection. We found that the mRNA and protein expression levels of $\mathrm{ER} \alpha, \mathrm{ER} \beta$ and PR were all elevated with an increase in FOXP1 expression $(P<0.05$ for all), indicating that FOXP1 has a positive regulating effect on the transcription of ER $\alpha, E R \beta$ and PR.

In addition to this, immunohistochemistry indicated the protein expression of FOXP1 correlated with that of the ER and PR. We found the expression of FOXP1 colocalized with the ER or PR in endometrial carcinoma cell line and tissues. Co-immunoprecipitation experiments highlighted interactions of FOXP1 with ER $\beta$ and interactions of $\mathrm{ER} \alpha$ with $\mathrm{ER} \beta$. ChIP experiment results suggested that both $\operatorname{ER} \alpha$ and $\operatorname{ER} \beta$ could bind to the transcriptional regulatory region of $F O X P 1$ to regulate the transcription of $F O X P 1$. Although the expression level of $\mathrm{ER} \beta$ was higher than $\mathrm{ER} \alpha, \mathrm{ER} \alpha$ seemed to play a more important role in the regulation of FOXP1 than ER $\beta$ considering the expression levels of $\mathrm{ER} \alpha$ and $\mathrm{ER} \beta$ and the amount of DNA fragments bound by ER $\alpha$ or ER $\beta$. All the results suggest that FOXP1, ER and PR have the same interaction or a synergistic effect in endometrial carcinoma.

However, this study had several limitations. Firstly, the majority of endometrial carcinoma patients experienced a recurrence 2-3 years after their operation, but a few patients in this study were followed up for less than 3 years, which may have led to a bias in the analysis of prognoses. Secondly, there were some cases of followup loss and only a few cases of death and recurrence in this study, so we will need to conduct future studies using a larger sample size.

Taken together, this study demonstrates that FOXP1 is poorly expressed in endometrial carcinoma and that the down-regulation of its expression plays an important role in the process of endometrial cancer. FOXP1 correlated positively with the expression of ER $\alpha, \operatorname{ER} \beta$ and PR. Patients with low FOXP1 expression displayed a shortened survival time. This may be explained by the fact that the absence of FOXP1 expression causes developmental defects in B cells and that patients on hormone therapy are insensitive to such therapy due 
to the low expression of ER. Overexpressed FOXP1 can up-regulate expression levels of ER and PR, and ChIP experiments confirmed that ER could regulate the transcription of FOXP1. FOXP1 could effect the expression of ER and PR. On the other hand, ER $\alpha$ seemed to play a role mainly through regulating the transcription of FOXP1, while ER $\beta$ mainly through the interaction with FOXP1. Under the treatments of estradiol or progesterone at different concentrations, FOXP1 and ER demonstrated similar changes in expression, indicating that FOXP1 is also regulated by progesterone. We presume that FOXP1 may be a part of the interactive network of estrogen, progesterone, ER and PR, and that FOXP1, ER and PR play an important role in the occurrence and development of endometrial carcinoma. FOXP1 may be considered a new target for the treatment of endometrial carcinoma and an indicator for the evaluation of prognoses. We intend to investigate the role of FOXP1 in endometrial carcinoma further and the mechanisms of mutual regulation between FOXP1, and the ER and PR.

\section{MATERIALS AND METHODS}

\section{Specimen sources}

Our study population consisted of 130 patients, and the specimens were collected during 2004 to 2013 from the operation of the Department of Obstetrics and Gynecology, Shengjing Hospital affiliated to China Medical University. The paraffin-fixed pathologic specimens had histopathologic-confirmed diagnoses by pathologists, as follows: endometrial carcinoma, $\mathrm{n}=90$; atypical hyperplasia of endometrium (mild hyperplasia, $\mathrm{n}=10$; moderate hyperplasia, $\mathrm{n}=8$; severe hyperplasia, $\mathrm{n}=10$ ), $\mathrm{n}=28$; and endometrium (secretory and proliferative phase, $n=6$ each), $n=12$. Normal endometrium specimens were collected from patients who had hysterectomies of the entire uterus due to cervical lesions, with no ovarian chocolate cysts, uterine myomas, or other female hormonedependent diseases in the normal endometrium and atypical hyperplasia groups. Patients in the endometrial carcinoma group were 36-79 years of age(average age 58.51 years), patients in the endometrial atypical hyperplasia group were 30-66 years of age(average age 45.30 years), and patients in the normal endometrium group were 39-53 years of age(average age 44.06 years); There were no statistically significant difference among the average ages of each group $(P>0.05)$. (clinicopathological parameters seen in Table 2 ). All the patients had primary endometrial carcinomas with complete clinical and pathologic data, and no patients received pre-operative chemotherapy, radiotherapy, or hormone therapy.

\section{Methods immunohistochemistry}

The endometrial tissue specimens were dissected using 5- $\mu \mathrm{m}$ serial consecutive sections. Expression of
FOXP1 was detected using streptavidin-peroxidase (SP) and Strept Avidin-Biotin Complex (SABC) immunohistochemistry staining, using rabbit anti-human FOXP1 antibodies (1:3000, Abcam). Positive and negative controls were routinely employed, Tonsil tissue served as a positive control for FOXP1, the negative control was incubated with PBS instead of primary antibody. The empirical procedure was performed based on the manufacturer's instructions.

Samples were marked positive when the cell nucleus or cytoplasm appeared brown or yellow. No pigmentation, light yellow, buffy, and brown are scored $0,1,2$, and 3, respectively according to the chromatosis intensity. We choose 5 high-power fields in series from each slice, then score them and take the mean percentage of the chromatosis cells: chromatosis cells that account less than $5 \%$ are $0,5 \%$ to $25 \%: 1,26 \%$ to $50 \%: 2,51 \%$ to $75 \%$ : 3 , and greater than 75\%: 4. Multiply these 2 numbers: 0 to 2 is considered $(-) ; 3$ to $4,(+) ; 5$ to $8,(++)$; and 9 to $12,(+++)$. The results were judged by two pathologists independently to control error.

\section{Transfection of ishikawa cells with lentivirus}

Suitable amount of Ishikawa cells were added in fresh medium to the well in a 6-well plate and incubated at $37^{\circ} \mathrm{C}$ in a humidified incubator in an atmosphere of $5 \% \mathrm{CO}_{2}$ until the cell confluence reached $30 \%-40 \%$. We removed medium and added $1 \mathrm{~mL}$ medium and $5 \mu \mathrm{L}$ polybrene to each well and gently swirled the plate to mix. Then added FOXP1 over-expression / control lentiviral particles to appropriate wells (both $\mathrm{MOI}=2$ ) and gently swirled the plate to mix. Cells were incubated 18-20 hours in the incubator and then removed the medium and added fresh medium to a volume of $2 \mathrm{~mL}$ to each well and continued to incubate. We observed the fluorescence of the cells after 3 days later. The transfection effect reached 70\%-80\%. Cells were selected by puromycin and the clones were expanded to assay for expression of FOXP1. Choose the best clone and continue to expand the cells to get stable cells.

\section{Quantitative real-time PCR}

Total RNA was extracted from cells with RNAiso Plus reagent (TAKARA) and reverse-transcribed by using a Prime-Script RT reagent Kit (TAKARA). Reaction conditions were $37^{\circ} \mathrm{C}$ for $15 \mathrm{~min}, 85^{\circ} \mathrm{C}$ for $5 \mathrm{~s}$ and $4^{\circ} \mathrm{C}$ for $5 \mathrm{~min}$. Real-time PCR was performed with a Applied Biosystems 7500 fast system. The real-time PCR reaction conditions were $95^{\circ} \mathrm{C}$ for $30 \mathrm{~s}, 40$ cycles of $95^{\circ} \mathrm{C}$ for $5 \mathrm{~s}$ and $60^{\circ} \mathrm{C}$ for $30 \mathrm{~s}$ in a $20 \mu \mathrm{L}$ reaction mixture containing cDNA 2 $\mu \mathrm{L}$, PCR Forward Primer( $10 \mu \mathrm{mol} / \mathrm{L}) 0.4 \mu \mathrm{L}$, PCR Reverse Primer(10 $\mathrm{mol} / \mathrm{L}) 0.4 \mu \mathrm{L}, \mathrm{SYBR} @$ Premix Ex Taq ${ }^{\mathrm{TM}}(2 \times)$ $10 \mu \mathrm{L}, \operatorname{ROX} 0.4 \mu \mathrm{L}, \mathrm{dH}_{2} \mathrm{O} 6.8 \mu \mathrm{L}$. $\beta$-actin was used as the endogenous control. Primers: FOXP1: 5'-CAGTGGTAA CCCTTCCCTT-3', 5'-CGTTCAGCTCTTCCCGTA-3'. $\mathrm{ER} \alpha: \quad$ 5'-CCTACTACCTGGAGAACGAGC-3', 
5'-CAGATTCCATAGCCATACTTCC-3'. ER $\beta$ : 5'-GGC AGACCACAAGCCCAAAT-3', 5'-CGCAGAAGTG AGCATCCC-3'. PR: 5'-GATTCAGAAGCCA GCCAGAG-3', 5'-ACAGCTCCCACAGGTAAGGA-3'. 3-actin: 5'-CAGCAAGCAGGAGTATGACG-3', 5'-TTAGGATGGCAAGGGACTTC-3'.

\section{Co-immunoprecipitation}

Ishikawa cells were plated in RPMI-1640 medium with $10 \%$ of fetal bovine serum albumin medium, and incubated in an incubator at $37^{\circ} \mathrm{C}$ under $5 \% \mathrm{CO}_{2}$. Rabbit anti-human FOXP1 antibodies, rabbit anti-human ER $\alpha$ antibodies and rabbit anti-human ER $\beta$ antibodies were purchased from Santa Cruz Biotechnology(Santa Cruz, CA, USA), and rabbit anti-human PR antibodies were purchased from Cell Signaling Technology(Danvers, MA, USA). Details of the experimental procedure have been published previously [5]. 4 coimmunoprecipitations were performed: (1) FOXP1 protein was precipitated with rabbit anti-human FOXP1 antibodies and detected using mouse anti-human ER $\alpha$ antibodies, and ER $\beta$ antigen detected using mouse anti-human ER $\beta$ antigen antibodies; (2) $E R \alpha$ protein was precipitated with rabbit anti-human ER $\alpha$ antibodies and detected with rabbit anti-human FOXP1 antibodies, and ER $\beta$ was detected with mouse anti-human ER $\beta$ antibodies; (3) ER $\beta$ protein was precipitated with rabbit anti-human ER $\beta$ antibodies and detected with rabbit anti-human FOXP1 antibodies, and ER $\alpha$ was detected with mouse anti-human ER $\alpha$ antibodies; The primary antibody was replaced by rabbit IgG(Bioss, China) as negative control. A chemoluminescence reagent was used (ECL Western Blotting Detection Reagent; Biotime, China), and the experiment was repeated three times.

\section{Western blotting}

Western blots were prepared as previously described [20], antibodies used were: rabbit anti-human FOXP1(1:2000, Abcam, USA), mouse anti-human ER $\alpha$ (1:100, Santa Cruz, USA), mouse anti-human ER $\beta$ (1:100, Santa Cruz, USA), and rabbit anti-human PR (1:1000, Cell Signaling Technology, Danvers, USA).

\section{Confocal laser scanning microscopy}

Three immunofluorescence double labeling experiments were carried out as previously described [5]. Protocols strictly followed the instructions of the reagent suppliers. (1) goat anti-human FOXP1 antibodies (1:500, Santa Cruz Biotechnology, CA, USA) and mouse antihuman ER $\alpha$ antigen antibodies or ER $\beta$ antibodies (both 1:50, Santa Cruz Biotechnology, CA, USA) or rabbit anti-human PR antigen antibodies (1:100, Cell Signaling Technology, Danvers, USA) were simultaneously added to monolayered cell slides prepared from Ishikawa cells and paraffin sections of endometrial cancer tissue. To these, the following secondary antibodies were applied: Tetramethylrhodamine (TRITC) red fluorescence-labeled goat $\operatorname{IgG}(1: 50)$ and fluorescein isothiocyanate (FITC) green fluorescence-labeled mouse IgG fluorescence (1:50) or fluorescein isothiocyanate (FITC) green fluorescencelabeled rabbit IgG fluorescence(1:50). Cell nucleus were stained with 4', 6-diamidino-2-phenylindole (DAPI). PBS replaced primary antibodies for negative controls. Doublelabeled immunofluorescence samples were viewed by fluorescence confocal microscopy.

\section{Chromatin immunoprecipitation (ChIP) assay}

ChIP assay and quantitative real-time reversed transcription polymerase chain reaction were performed as previously described [7]. Ishikawa cells were fixed in $37 \%$ formaldehyde for $10 \mathrm{~min}$ at room temperature. Chromatin was sheared to the size of $100-500$ bp by Enzymatic shearing cocktail(Active Motif, Carlsbad, USA). Lysates were rotated at $4^{\circ} \mathrm{C}$ overnight with a specific antibody against ER $\alpha$ or ER $\beta$ and protein $G$ magnetic beads. Precipitated DNA was used as a template for real-time PCR using an Applied Biosystems 7500 fast system based on SYBR Green fluorescence. A genomic fragment containing ERE in the enhancer region of TFF1 acted as a positive control for ER binding. Primers: TFF1ERE: 5'-TGAGATTCAGAAAGTCCCTCTTTC-3', 5'-TGGGCTTCATGAGCTCCTT-3'. FOXP1-ER-1: 5'-AACATCTGACAAATTATTGGGTGGTT-3', 5'-TG GCTTACCAGTTTAATGTCCCATA-3'. FOXP1ER-2: 5'-AGGGTGAACCACAGCCTGTT-3', 5'-AA AGTGACAGTTTCCCAAGTACATGT-3'. FOXP1ER-3: 5'-TGCAAGGTCTGTTTAACAGACACA-3', 5'-ACAGCTCCCACAGGTAAGGA-3'.

$\beta$-actin: 5'-CAGCAAGCAGGAGTATGACG-3', 5'-TTAGGATGGCAAGGGACTTC-3'.

\section{Statistical analysis}

SPSS19.0 software was used for statistical analysis. T-test, $\mathrm{c}^{2}$ analysis and variance analysis were employed. Kaplan-Meier and log-rank methods were applied to analyze survival curves. Cox regression model was applied for analysis of risk factors. Spearman correlation analysis was applied to analyze the correlation between two proteins. $P<0.05$ was considered statistically significant.

\section{CONFLICTS OF INTEREST}

The authors declare no conflicts of interest.

\section{FUNDING}

This work was supported by the National Natural Science Foundation of China (Grant No:81172491, 81101527, 81472437, 81402129); the 
Specialized Research Fund for Dr. Of Colleges (Grant No:20112104110016, 20112104120019) and the Outstanding Scientific Fund of Shengjing Hospital (Grant No:201303).

\section{REFERENCES}

1. Siegel R, Ma J, Zou Z, Jemal A. Cancer statistics, 2014. CA Cancer J Clin. 2014; 64:9-29.

2. Hill E, Dizon D. Medical therapy of endometrial cancer: current status and promising novel treatments. Drugs. 2012; 72:705-713.

3. Bryant W, Snowhite A, Rice L, Shupnik M. The estrogen receptor (ER)alpha variant Delta5 exhibits dominant positive activity on ER-regulated promoters in endometrial carcinoma cells. Endocrinology. 2005; 146:751-759.

4. Shu W, Yang H, Zhang L, Lu MM, Morrisey EE. Characterization of a new subfamily of winged-helix/ forkhead (Fox) genes that are expressed in the lung and act as transcriptional repressors. J Biol Chem. 2001; 276:27488-27497.

5. Hu Z, Zhu L, Tan M, Cai M, Deng L, Yu G, Liu D, Liu $\mathrm{J}$, Lin B. The expression and correlation between the transcription factor FOXP1 and estrogen receptors in epithelial ovarian cancer. Biochimie. 2015; 109:42-48.

6. Dmitriev AA, Rudenko EE, Kudryavtseva AV, Krasnov GS, Gordiyuk VV, Melnikova NV, Stakhovsky EO, Kononenko OA, Pavlova LS, Kondratieva TT. Epigenetic alterations of chromosome 3 revealed by NotI-microarrays in clear cell renal cell carcinoma. Biomed Res Int. 2014; 2014:957-964.

7. Shigekawa T, Ijichi N, Ikeda K, Horie-Inoue K, Shimizu C, Saji S, Aogi K, Tsuda H, Osaki A, Saeki T, Inoue S. FOXP1, an estrogen-inducible transcription factor, modulates cell proliferation in breast cancer cells and 5-year recurrencefree survival of patients with tamoxifen-treated breast cancer. Horm Cancer. 2011; 2:286

8. Yamamoto K, Ito S, Hanafusa H, Shimizu K, Ouchida M. Uncovering direct targets of MiR-19a involved in lung cancer progression. PLoS One. 2015; 10:e137887.

9. Taylor B, Schultz N, Hieronymus H, Gopalan A, Xiao Y, Carver B, Arora V, Kaushik P, Cerami E, Reva B, Antipin Y, Mitsiades N, Landers T, et al. Integrative genomic profiling of human prostate cancer. Cancer Cell. 2010; 18:11-22.

10. Zhu L, Hu Z, Liu J, Gao J, Lin B. Gene expression profile analysis identifies metastasis and chemoresistanceassociated genes in epithelial ovarian carcinoma cells. Med Oncol. 2015; 32:1-13.
11. Hans CP, Weisenburger DD, Greiner TC, Gascoyne RD, Delabie J, Ott G, Müller-Hermelink HK, Campo E, Braziel RM, Jaffe ES, Pan Z, Farinha P, Smith LM, et al. Confirmation of the molecular classification of diffuse large B-cell lymphoma by immunohistochemistry using a tissue microarray. Blood. 2004; 103:275-282.

12. Banham AH, Beasley N, Campo E, Fernandez PL, Fidler C, Gatter K, Jones M, Mason DY, Prime JE, Trougouboff P. The FOXP1 winged helix transcription factor is a novel candidate tumor suppressor gene on chromosome $3 \mathrm{p}$. Cancer Res. 2001; 61:8820-8829.

13. Hirakawa $\mathrm{H}$, Yokoyama $\mathrm{Y}$, Yoshida H, Mizunuma $\mathrm{H}$. Inhibitory effects of aromatase inhibitor on estrogen receptor-alpha positive ovarian cancer in mice. J Ovarian Res. 2014; 7:1-8.

14. Giatromanolaki A, Koukourakis MI, Sivridis E, Gatter $\mathrm{KC}$, Harris AL, Banham AH. Loss of expression and nuclear/cytoplasmic localization of the FOXP1 forkhead transcription factor are common events in early endometrial cancer: relationship with estrogen receptors and HIF-1alpha expression. Mod Pathol. 2006; 19:9-16.

15. Fu L, Girling JE, Rogers PA. Expression of Fox head protein 1 in human eutopic endometrium and endometriosis. Reprod Sci. 2008; 15:243-252.

16. Mizunuma M, Yokoyama $\mathrm{Y}$, Futagami $\mathrm{M}$, Horie $\mathrm{K}$, Watanabe J, Mizunuma H. FOXP1 forkhead transcription factor is associated with the pathogenesis of endometrial cancer. Heliyon. 2016; 2:e116.

17. Hu H, Wang B, Borde M, Nardone J, Maika S, Allred L, Tucker PW, Rao A. Foxp1 is an essential transcriptional regulator of B cell development. Nat Immunol. 2006; $7: 819-826$

18. Ijichi N, Shigekawa T, Ikeda K, Horie-Inoue K, Shimizu C, Saji S, Aogi K, Tsuda H, Osaki A, Saeki T. Association of double-positive FOXA1 and FOXP1 immunoreactivities with favorable prognosis of tamoxifen-treated breast cancer patients. Horm Cancer. 2012; 3:147-159.

19. Rayoo M, Yan M, Takano E, Bates G, Brown P, Banham A, Fox S. Expression of the forkhead box transcription factor FOXP1 is associated with oestrogen receptor alpha, oestrogen receptor beta and improved survival in familial breast cancers. J Clin Pathol. 2009; 62:896-902.

20. Bot PT, Grundmann S, Goumans MJ, Kleijn DD, Moll F, Boer OD, van der Wal AC, Soest AV, de Vries JP, Royen NV. Forkhead box protein P1 as a downstream target of transforming growth factor- $\beta$ induces collagen synthesis and correlates with a more stable plaque phenotype. Atherosclerosis. 2011; 218:33-43. 